\title{
RISKS, THREATS AND VULNERABILITIES AT THE EASTERN BORDER OF NATO AND OF THE EU Ionel-Claudiu PASĂRE
}

\author{
"Mihai Viteazul" National Intelligence Academy, Bucharest, \\ claudiupasare@yahoo.com
}

\begin{abstract}
The twenty first century has presented us with distinctly new kinds of security challenges. These new challenges have specific information components. In some cases, the crisis is essentially about information such as cyber-attacks against government or critical private sector information systems. In others, the information needs for crisis managers are critical but do not yet enjoy a robust infrastructure. The risk of a traditional war on the European continent is not the same as during the Cold War. Nevertheless, at sub-regional level there still occur phenomena of instability and crisis and trends of fragmentation and isolation of certain states.

"The current crisis in Ukraine is affecting as a whole, the strategic interests of the Romania in the Region, and I think at issues like: the border security of NATO and EU, the European path of the Republic of Moldova, the situation of Romanians in Ukraine, the democratization of the Wider Black Sea Region and ensuring of energy security" (Eduard Hellvig, SRI director, AGERPRESS interview, March 31, 2015)”.
\end{abstract}

\section{Keywords: intelligence, threats, cooperation, vulnerabilities, security}

\section{Introduction}

The $21^{\text {st }}$ century is evolving towards a multi-polar world in which the affirmation and consecration of the new planetary leaders constitutes in a real competition. Also an increase in interdependence and interaction levels between world states, make possible the emphasis of the civilization transfer from West (including the US) to East (Russia included), after the dismantling process of the communist system. This phenomenon is circumscribed within globalization trends marked by its two dimensions. Continental, managed by the Western European countries and the global dimension, controlled by the United States, thus directing the efforts of the EU and NATO integration of ex-communist countries.

The phenomenon of globalization, European and Euro-Atlantic integration efforts made by the group of the former socialist countries, revival of the offensive spirit of Russia on the international arena, an ever stronger assertion of Asia in the world politics, alongside with the reconsideration of the role of the Arab countries in peacekeeping process of the Middle East, decisively determines the evolution of the security environment. However phenomena of instability and crisis, persists at sub-regional level given the trends of fragmentation, marginalization and isolation of some states. Countries from Central, Eastern and South-Eastern Europe are facing economic, social and political difficulties associated with the transition process towards a society based on the principles of Democracy and market economy, can pose significant risks to security of the states in the region. 


\section{Russia and Ukraine}

Since 2012, the Russian Federation initiated propaganda informational attacks against several countries including Romania, using different media tools, such as the radio station, Voice of Russia (The Romanian version of the Voice of Russia has ceased to broadcast on $25^{\text {th }}$ of December 2014. According to an official statement of the station "decision rests with management international news agency Russia Today to the reorganization of the institution's work"). However, hybrid warfare tactics applied by the Russians in eastern Ukraine are not feasible in Romania due to the lack of the Russian minority in Romania that can be used for a potential insurrection, and to justify the invasion by the Russian troops under the pretext of protecting the interests of the Russian minority. Thus, the main weapon of the Russian Federation in attacking Romania is represented by the use of propaganda or informational warfare.

The threat of the Russian informational war is favored by certain internal factors such as the lack of professionalism among the journalists and their need for sensational (the situation of the Romanian consul in Chisinau, filmed during intercourse, case intensely publicized in the Romanian press). Another contributing factor is represented by the lack of competent human resources needed in order to counter the Russian propaganda, given the fact that Romania did not face in the recent times such a phenomenon. An important role in the counter-propaganda activities is played by the intelligence agencies. In addition, the Russian Federation carries out patrol missions in the vicinity of the Romanian territory using military aircrafts, thus forcing a reaction from Romania. In the event of a military attack on the behalf of the Russian Federation, the most likely targets would consist of the two command centers that NATO will deploy in Romania and the Romanian military fleet. Although NATO has a declared defensive nature, the Kremlin considers its expansion as a challenge to their authority, given the NATO's held offensive potential.

The NATO and the EU resizes have caused numerous and consistent changes in trends and attitudes in the East-West relations which increased Moscow's frustrations. In the new geopolitical configuration at the beginning of the millennium, Moscow seeks to retain the status of the second world power, which is why it is trying to impose by all means its superior authority in the former Soviet space. In this context, Ukraine, located in Eastern Europe, became the largest piece in the competition for influence between Russia, NATO and the EU against the backdrop of Russia's intention to strengthen its position in the former Soviet space on the edge with the West. Russia senses the danger posed by its diminishing political, military and economic influence in the world and feels threatened by EU and NATO enlargement to the East. Under these circumstances, there is a tendency for Russia to assert its primacy, to strengthen and maintain influence in its neighborhood and to establish a new Eastern block. However, NATO and the EU, does not support the negotiations with the Russian Federation in a block against block approach, opting for the solution development of bilateral relations with individual countries. The situation is similar in the case of Ukraine, which established special relations with NATO and the EU, actively participating in national and regional security missions undertaken by these countries, including in Iraq.

Highlighting the interoperability relations between the two "actors" responsible for the security and development of the European continent, as well as stressing the main issues underlying historical and current stage of development in the countries of Central and Eastern Europe is a key step approach to the analysis of risk factors on the eastern border of NATO and the EU. The risk factor can be defined as the part of the system which, under certain conditions, 
passing from dormant to an active state, becomes a potential cause of the crisis with specific ways of expression due to its nature. The existence in a defined geographical area of several risk factors of the same or of a different kind is an area of risk when activated causes crises or major crisis situations of different intensities. The state border can be defined as a legal limit in which the state exercises its absolute and exclusive sovereignty and the nation its right to self-determination.

\section{Romania - strategic border for NATO and the European Union}

Romania is located at the intersection of three strategic dynamics, namely: Russian Federation's space with a relatively unstable economy, but still a powerful military point; the Central-European space which is integrated into NATO; SouthEastern European space remains the main supplier of uncertainty and instability. In this context, Romania, as a NATO member state has to play an important role in ensuring the peace and security of the region. Regional cooperation in the security field is materialized in the existence of a large number of organizations (Baltic Council, Visegrad Group, Black Sea Economic Cooperation Organization, Central European Free Trade Area CEFTA, the Central European Initiative CEI Cooperation Initiative in South eastSECI, Stability Pact in Southeast Europe, etc.) - offers the opportunity to improve common mechanisms of strategic environmental assessment, to identify a common risks agenda and to appropriate tools for crisis management. Synchronizing common efforts and the orientation of their activities in complete harmony with NATO and EU efforts, especially increasing responsibility of the Southeast European states, their leaders and national political forces in order to provide security in the region by increasing their contribution for finding solutions to tensions, crisis and conflicts, that are in fact the major imperatives of the new regional security paradigm.

The National Security Strategy of Romania analyzes the risks and threats to national security, perceived in terms of its status as a member-state of the North - Atlantic Alliance and the European Union. Although the threat of a classical war, of a conventional military aggression is unlikely to happen, the neglect of such risks could cause major vulnerabilities to national security and affect the capacity of action in order to fulfill the international obligations. In this category are included risks and threats associated to security and border defense, given the fact that main segments of the Romanian borders are an important part of the eastern land border system of the two organizations. The main risks and threats of political, economic, social and military nature, which are likely to endanger the security of Romania, NATO and the EU are: international terrorism structured in cross-border networks; proliferation of weapons of mass destruction; regional conflicts; organized transnational crime and poor governance.

\section{Threats for our regional security}

International terrorism structured in crossborder networks is the most serious threat to human life, freedom, democracy and other fundamental values upon which the democratic community of Euro-Atlantic states was built.

International terrorist networks can gain access to modern technology and can use banking tools (transfers), rapid means of communication, infrastructure and assistance provided by extremist organizations, the cross-border support of organized crime or receiving shelter and aid from corrupt regimes which are unable to govern democratically. Terrorist networks can also cause massive loss of lives, goods, while, due to the access to weapons of mass destruction, the consequences of their actions can become devastating. The open nature of modern democratic societies, and how complex and contradictory in manifesting various processes of 
globalization really are, the emphasis on the vulnerability of all States, both at the level of individual countries and the international community as a whole is necessary. The proliferation of weapons of mass destruction: nuclear, chemical, biological and radiological constitute a particularly serious threat in terms of the potential for destruction, given that, the access to such resources becomes easier, therefore increases the temptation of acquiring and use is rising menacingly.

Simultaneously, it is decreasing the responsibility level of the authorities which have in their possession such capabilities, especially in the case of certain regimes which are animated by extremist, political or religious ideologies. It is estimated that the number of cruise and long-range ballistic missiles will grow and their use in action, in the theater of the military operations will increase significantly, especially in the Middle East. This development has the potential to fundamentally change the balance of forces in the theater of military action, the character of war and regional conflict. Regional conflicts have strong implications for regional and European peace and security. Product of a more or less violent disappearance of the multinational states in the area, these ethnic or religious conflicts have strong political components and represent a serious threat to regional security, given the major efforts of the international community, most of them are controlled. Given their large number, these conflicts alongside other tensions, separatist movements, territorial disputes and crises in the proximity of Romania - generate uncertainty, waste of the resources and perpetuate poverty. They also fuel other forms of violence and crime and favoring terrorism. If we would have to draw a circle with a radius of $1600 \mathrm{~km}$ and with the center in Ankara, it would contain both the crossroads of the eastern hemisphere and the eternal center of political crisis from the Roman Empire until today. Over the centuries, every inch of this area was in a conflict; empires were created and destroyed in this area; no global power can exist unless it defines its policy in the Eastern Hemisphere. Small and difficult regional geopolitics makes the foreigners to believe that it's better to avoid this area, but this thing is actually impossible. Europe is not safe without a secure area in the Balkans.

Transnational Organized Crime is a form of a very serious crime, which has acquired the ability to influence the state policies and activities of the democratic institutions. It is both an expression of the proliferation of some negative phenomena which are amplifying in the context of globalization, as well as a direct consequence of the inefficient management of political, economic and social changes that have occurred in the central, eastern and southeastern Europe after the collapse of the communist regimes. Given the context posed by such a situation, the area of strategic interest in which Romania is positioned, was transformed into a genuine source, transit and destination area for serious criminal activities consisting mainly from: illegal trafficking of arms ammunition and explosives; narcotics trafficking; illegal migration and human trafficking; trafficking in counterfeit goods; money laundering activities alongside other forms of economic and financial crime. These kinds of activities are favored by the existence of the local conflicts and, by taking into account their nature and extent; they can foster terrorism and proliferation of weapons of mass destruction and contribute to the perpetuation of separatist regimes. Illegal migration is controlled by large international mafia structures, especially of Russian origin. As a result of measures undertaken by the EU Member States to tackle this phenomenon, it is expected to be produced some mutations in terms of illegal migration routes from Asia (Afghanistan, Pakistan, Iran, Iraq, Sri Lanka, Bangladesh, India, etc.) to Western 
Europe through the enhanced migration flows via the CIS.

In this kind of perspective, Romania plays a key role in securing the eastern border of NATO and the EU. The region is crossed by the routes for trafficking drugs from the Golden Crescent (Pakistan, Iran, Afghanistan), Golden Triangle (Myanmar, Laos, Thailand) and from some Central Asian states, the persistent outbreaks of conflict favors the growth and the reshaping of the organized crime activities, which gained an obvious transnational character. The permeability of borders in the Caucasus foster development of the activities of organized crime, leading to increased risk factors and threats to security in the region. By extension, after the transition of the area, the organized crime linked activities reach Western European countries which are confronted with illegal migration and trafficking in narcotics.

An important role in strengthening stability and security process of the new democracies in Central, Eastern and Southeast lies to the capacity of the states and of the societies to promote effective management of public interests, meaning good governance, where the majority of the states in this region have made substantial achievements since the collapse of communist regimes. However, new democracies still face various negative phenomena, the effects of ineffective governance, which is undermining citizens' confidence in public institutions and may constitute a threat to the states security. Poor governance can jeopardize the normal exercise of fundamental human rights and freedoms and even affect the fulfillment of international obligations, creating the risk of humanitarian crises with a cross-border impact.

In the same field of risk factors at the eastern border of NATO and the EU, the Black Sea Region has to be analyzed. Both for Romania and for other countries that have this natural border, building a system of security and prosperity in the Black Sea area is a distinct course of action of this strategy. Located at the crossroads of three areas of great importance - Europe, Middle East and Central Asia - the Black Sea region is a major transit area for energy resources and also an important place for the occurrence of asymmetric risks and outbreaks of conflict, with a significant impact on Euro-Atlantic security. Far from the possibility of being simply considered a mere buffer or peripheral are, the Black Sea region is of paramount importance connector, located on the corridor linking the Euro-Atlantic community (as a security provider and consumer of energy) with the strategic extended area of Middle East Caspian Region - Central Asia (as an energy supplier and security consumer). In terms of energy, the Black Sea region is the main transit area and a major source of resources that are consumed in Europe, while forecasts are envisaging the possibility of substantial increase in its quantity in the coming decades, which gives it a crucial role in Europe's energy security.

In terms of security challenges, the region is an objective mirror of new risks and threats and a potential hub for their experimentation. In this respect it should be mentioned the specific risks and threats of this area, without insisting on those which were already analyzed.

The terrorism, understood as criminal attacks, illegal fundraising activities and money laundering and the possibilities for recruitment, training and housing, especially in the separatist regions beyond the control of legitimate authorities, poses a great threat to the regional security as a whole. The proliferation of weapons of mass destruction takes the form of trafficking in radioactive materials, special technology and know-how needed to build weapons of mass destruction and their means of delivery. The collapse of the USSR, partial dismantling of the industries producing weapons of mass destruction, the reduced rigor of control over the arsenals holders and the existence of huge stockpiles 
of such materials in the regions where are not controlled by the competent authorities, makes this region a very dangerous black market for the proliferation of weapons of mass destruction. Frozen conflicts: The Black Sea Region is the most abundant part of Europe in terms of these types of conflicts, tense situations and disputes. The "classic" separatist conflicts in Eastern Moldova (Transnistria), eastern and northern Georgia (Abkhazia and South Ossetia), Eastern Azerbaijan (NagornoKarabakh), Southern Russia (Chechnya and other republics or autonomous regions in the Northern Caucasus), other separatist movements of smaller scale and intensity, and tensions related to disputes over territory or borderlines poses serious threats to the security of the region and creates the premises for the reigniting the conflict.

The illegal trafficking of weapons, ammunition, explosives, drugs, human trafficking, illegal migration and other aspects of organized cross-border crime, all of these are painting a grim landscape of the region. These activities are conducted on land and water and are organized mainly on the old structures of intelligence cooperation networks of the former USSR, having connections with international terrorist groups and being favored by separatist movements and regimes also benefiting from the illegal presence of foreign troops on the sovereign soil of new democracies.

Countering these risks and threats is, above all, a primary responsibility of the states bordering the Black Sea. First, they must be aware of these dangers and are obliged to develop domestic, foreign and security policies which are able to neutralize the negative phenomena within their borders and to restrain themselves in any way possible from supporting any kind of separatist movements, extremist organizations or terrorist and criminal activities. At the same time, based on the indivisibility of the security in the EuroAtlantic area in line with the requirements of globalization, from the need for equal treatment of all entities that have interests in the area - including NATO and the European Union - Romania considers that the Black Sea region is a geopolitical space open to international democratic community where the partner, friendly and allied countries can express themselves. Romania also actively promotes the necessity of defining and implementing a Euro-Atlantic strategy for the Black Sea region, taking into account the experience of NATO-EU joint approach in the stabilization of South - Eastern Europe and the need for balance arrangements to promote democratic option states, to prevent worsening of risks and threats and to contribute actively and effectively to the resolution of conflicts, tension and disputes. European Union, on the $1^{\text {st }}$ of January 2007 became the western border of the Wider Black Sea Region, and it will face challenges posed by its specific risk factors, subsumed under various threats faced by the entire international community.

Extension of the European Union's responsibilities in stabilizing and rebuilding the region, strengthening the presence and contribution of NATO and Partnership for Peace Program in the processes of democracy promotion, peace and security, as well as the presence of some American operational capabilities in the region, are factors of vital importance able to contribute to the foundation of this kind of strategy.

Romania's interest is that the process of enlargement of the two organizations does not lead to the creation of new dividing lines in the Black Sea region so that our country will effectively support the prospect of European and Euro-Atlantic integration of the neighboring states. On the basis of a special relationship between Romania and Moldova in line with the responsibilities arising from the common historical background, language and culture with the principle of "one nation - two states" and with the spirit of the European 
Neighborhood Policy, we will pay a special attention to cooperation with Moldova. Romania has the political and moral obligation to support this country in its process of modernization, democratization and European integration and to do everything possible to support - in terms of political, economic and diplomatic sovereignty principle and territorial integrity, also to increase our contribution in the expansion of the area of security and prosperity. To this end, we will continue to monitor closely the developments in the Transnistrian conflict, to contribute actively in identifying viable solutions - based on the democratization and demilitarization of the region, on the withdrawal of the illegal weapons and stationed troops in the leftBank of Dniester River and to support the decisive involvement of the EU and US in the peace process.

Concluding it is important to point that the issue of risk factors analysis present at the eastern border of NATO and the EU is a very complex one, in agreement with the new security framework in Europe and marked by the permanent tense conditions occurring in this region of the globe. Therefore it is required a thorough analysis of the crisis phenomena, forms, methods of action and combat forces for crisis management.

\section{References}

[1] Aldrich, J., Richard, Global Intelligence Co-operation versus Accountability: New Facets to an Old Problem, articol în Revista Intelligence and National Security, Editura Routledge - Taylor\&Francis Group, februarie 2009

[2] Baylis, J., Smith, The Globalisation of World Politics, Oxford University Press, Londra, 2005

[3] Cearapin, Tudor, Homotescu, Gabriel and Toma, Gheorghe, From individual to collective security, Ed. Bioterra, Bucharest, 2003

[4] Desch, C., Michael, Intelligence Strategy: New challenges and opportunities Conference Proceedings, National Defence Intelligence College, Washinghton D.C., octombrie 2008

[5] Hertzberger, R., Eveline, Counter Terrorism Intelligence Cooperation in the European Union, European Foreign and Security Studies Policy Program; 2009

[6] Maior, George, Cristian, autor al studiului introductive al lucrării lui Steve Tsang, Serviciile de informaţii şi drepturile omului în era terorismului global. Geopolitica lumilor secolului XXI, trad. Irina Bondar, Cristina Dogaru, Laura Drăghici, Adelina Negoiţă, Editura Univers Enciclopedic, Bucureşti, 2008

[7] Onişor, Constantin, Frunzăverde, Sorin, South-Eastern Europe: Main dimensions of security, A'92 Publishing, Bucharest, 2004

[8] Pasăre, Ionel-Claudiu, NATO-transformation and new challenges, National Intelligence Academy Press "Mihai Viteazul", Bucharest, 2012

[9] Tsang, Steve, Serviciile de informatii si drepturile omului în era terorismului global. Geopolitica lumilor secolului XXI, Editura Univers Enciclopedic, Bucureşti, 2009

[10] Fota, Iulian, interview within the TV channel Digi 24, 16.02.2015

[11] The National Security Strategy of Romania, 2007 